\title{
Pengalaman, Due Professional Care, Akuntabilitas dan Kualitas Audit
}

\author{
Henni Andriani ${ }^{1}$, Suratno ${ }^{2}$, Muhammad Yusuf ${ }^{3}$ \\ ${ }^{123}$ Universitas Pancasila, Jakarta, Indonesia
}

\author{
A R T I C L E I N F O \\ JEL Classification: \\ M42, L84 \\ Key words: \\ experience, due professional care, \\ accountability, audit quality.
}

\begin{abstract}
A B S T R A C T
This research was aimed to analyze and provide empirical evidences about the impact of experience, due professional care, and accountability on audit quality. This study was conducted by using survey method with questionnaire. The population in this study are auditors who work in Inspectorate General of the Ministry of Health. This study used convenience sampling which was conducted by determination of samples counted with Slovin formula, so that only 89 questionnaires could be processed. Data analysis wasconducted using multiple regression model. The result proved that experience, due professional care, and accountability on audit quality simultaneously. Besides that, this study proved that e, due professional care, and accountability, audit quality partially, but experienc didn't influence audit quality..
\end{abstract}

\begin{abstract}
A B S T R A K
Tujuan penelitian ini yaitu untuk mengetahui, menganalisis dan mendapatkan bukti empiris tentang pengaruh pengalaman, due professional care, dan akuntabilitas terhadap kualitas audit yang dimiliki auditor Inspektorat Jenderal Kementerian Kesehatan RI. Metode yang digunakan adalah survei dengan kuesioner. Populasi penelitian ini adalah semua auditor yang bekerja pada Inspektorat Jenderal Kementerian Kesehatan RI. Data dianalisis dengan melakukan uji validitas dan reliabilitas, uji asumsi klasik dan pengujian hipotesis dengan metode regresi linier berganda. Data yang digunakan untuk penelitian ini yaitu data primer dengan menyebarkan kuesioner kepada 89 responden. Hasil yang diperoleh menunjukkan bahwa secara simultan faktor pengalaman, due professional care dan akuntabilitas mempengaruhi kualitas audit, secara parsial due professional care dan akuntabilitas mempengaruhi kualitas audit, sedangkan pengalaman tidak berpengaruh terhadap kualitas audit.
\end{abstract}

\section{PENDAHULUAN}

Inspektorat Jenderal Kementerian Kesehatan RI merupakan salah satu pengawas intern di lingkungan pemerintahan. Dalam upaya pemantauan terhadap kinerja unit organisasi yang ada dalam kendalinya, Inspektorat Jenderal Kementerian Kesehatan RI memiliki kegiatan utama yaitu audit, reviu, pemantauan, evaluasi, dan kegiatan pengawasan lainnya berupa sosialisasi, asistensi dan konsultansi.

Sesuai dengan Peraturan Menteri Kesehatan RI No. 1144/MENKES/PER/VIII/2010 tentang organisasi dan tata kerja Kementerian Kesehatan, Inspektorat Jenderal adalah unsur pengawas dan mempunyai tugas melaksanakan pengawasan intern di lingkungan Kementerian Kesehatan dan berfungsi sebagai pelaksana pengawasan intern di lingkungan Kementerian Kesehatan terhadap kinerja dan keuangan melalui audit, reviu, evaluasi, pemantauan dan kegiatan pengawasan lainnya, serta pelaksanaan pengawasan untuk tujuan tertentu atas penugasan Menteri Kesehatan.

Pelaksanaan audit yang dilakukan oleh auditor Inspektorat Kementerian Kesehatan RI pada umumnya terdiri atas audit kinerja/operasional dan audit investigatif. Audit kinerja/operasional adalah audit atas pelaksanaan tugas dan fungsi instansi pemerintah yang terdiri atas audit aspek ekonomi, efisiensi dan audit aspek efektifitas. Sedangkan audit investigatif adalah proses mencari, menemukan dan mengumpulkan

\footnotetext{
*Email Korespondensi: ${ }^{1}$ henniandriani@gmail.com
} 
bukti secara sistematis yang bertujuan mengungkapkan terjadi atau tidaknya suatu perbuatan dan pelakunya guna dilakukan tindakan hukum selanjutnya.

Belum dapat terdeteksinya penemuan dan melaporkan penyelewengan pada suatu entitas oleh auditor Inspektorat Jenderal Kementerian Kesehatan RI, terbukti dengan masih banyaknya temuan BPK. Hal ini tergambar dari hasil audit terhadap Laporan Keuangan Kementerian Kesehatan RI yang dilakukan oleh
BPK selama 4 (empat) tahun berturut-turut (2010-2013) yang masih menemukan adanya ketidakpatuhan terhadap undang-undang yang menyebabkan kerugian negara sebanyak 16 temuan senilai Rp81.548.424.797,- dan temuan terhadap Sistem Pengendalian Internal (SPI) sebanyak 21 temuan senilai Rp14.769.196.914.184,-. Kondisi tersebut dapat dilihat pada tabel berikut:

Tabel 1.1

Rekapitulasi Temuan Ketidakpatuhan Terhadap Perundang-Undangan dan Temuan Sistem Pengendalian Intern Pada Kementerian Kesehatan RI Tahun 2010-2013

\begin{tabular}{|c|c|c|c|c|c|}
\hline \multirow{2}{*}{ No } & \multirow{2}{*}{ Tahun } & \multicolumn{2}{|c|}{$\begin{array}{l}\text { Ketidakpatuhan Terhadap } \\
\text { Perundang-undangan }\end{array}$} & \multicolumn{2}{|c|}{ SPI } \\
\hline & & $\begin{array}{l}\text { Jumlah } \\
\text { Temuan }\end{array}$ & $\begin{array}{l}\text { Nilai } \\
(\mathrm{Rp})\end{array}$ & $\begin{array}{l}\text { Jumlah } \\
\text { Temuan }\end{array}$ & $\begin{array}{l}\text { Nilai } \\
(\mathrm{Rp})\end{array}$ \\
\hline 1. & 2010 & 3 & 4.979 .162 .891 & 6 & 2.047 .642 .963 .409 \\
\hline 2. & 2011 & 2 & 23.206.910.624 & 3 & 11.527.882.906.981 \\
\hline 3. & 2012 & 6 & 42.077.147.023 & 3 & 1.035893.208.595 \\
\hline 4. & 2013 & 5 & 11.285 .204 .259 & 9 & 157.777.835.198 \\
\hline & Jumlah & 16 & 81.548 .424 .797 & 21 & 14.769 .196 .914 .184 \\
\hline
\end{tabular}
Sumber: LKPP Tahun 2010-2013

Berdasarkan dari hasil audit yang diakukan oleh BPK terhadap LKPP tahun 20102013 tersebut, penyebab terjadinya temuan terhadap Kepatuhan Terhadap Pera-turan Perundang-undangan dan SPI tersebut secara umum yaitu kegiatan pengawasan dan pengendalian belum optimal sehingga di-harapkan peran Aparat Pengawas Intern Pemerintah agar ditingkatkan.

Selain probabilitas seorang auditor untuk dapat menemukan dan melaporkan sua-tu diukur dari tindak lanjut hasil audit yang dilakukan oleh auditee.

Berdasarkan laporan dari bagian Ana-lisis dan Pemantauan Tindak Lanjut Hasil Pemeriksaan (APTLHP) Inspektorat Jenderal Kementerian Kesehatan RI, diketahui bahwa, temuan dari hasil pemeriksaan yang dilakukan oleh auditor periode 2009-2013 belum dapat ditindaklanjuti seluruhnya oleh auditee, hal ini dapat dilihat pada tabel berikut: penyelewengan yang terjadi dalam sistem akuntansi klien, kualitas audit juga dapat

Tabel 1.2 Rekapitulasi Tindak Lanjut Hasil Audit (LHA) Pada Kementerian Kesehatan RI Tahun 2014

\begin{tabular}{|c|c|c|c|c|c|c|c|}
\hline \multirow{2}{*}{ No } & \multirow{2}{*}{ Unit Utama } & \multicolumn{2}{|c|}{ Status LHA } & \multicolumn{2}{|c|}{ Status Temuan } & \multicolumn{2}{|c|}{ Status Saran } \\
\hline & & Jumlah & Tuntas & Jumlah & Tuntas & Jumlah & Tuntas \\
\hline 1 & Sekretariat Jenderal & 575 & 49 & 1,657 & 192 & 3,256 & 368 \\
\hline 2 & Ditjen Bina Gizi dan KIA & 1,547 & 110 & 4,076 & 558 & 7,311 & 871 \\
\hline 3 & Ditjen Bina Upaya Kes & 1,564 & 136 & 4,717 & 628 & 9,248 & 901 \\
\hline 4 & Ditjen PPP dan PL & 824 & 83 & 2,571 & 452 & 5,878 & 708 \\
\hline 5 & Ditjen Bina Yanfar & 222 & 9 & 510 & 28 & 711 & 41 \\
\hline 6 & Badan Litbang & 106 & 8 & 348 & 46 & 741 & 70 \\
\hline 7 & Badan PPSDM & 688 & 65 & 2,501 & 372 & 5,779 & 626 \\
\hline & Total & 5,526 & 460 & 16,380 & 2,276 & 32,924 & 3,585 \\
\hline
\end{tabular}

Sumber: Bagian APTLHP bulan Desember 2014

Tabel di atas memperlihatkan bahwa jumlah LHA sebanyak 5.526 LHA, sedangkan yang telah tuntas hanya sebanyak 460 LHA $(8,47 \%)$, jumlah temuan sebanyak 16.380 
temuan dan tuntas hanya sebanyak 2.276 $(13,89 \%)$, dan jumlah saran sebanyak 32.924 saran hanya sebanyak 3.585 saran yang dinyatakan tuntas atau sekitar $10,88 \%$. Untuk lebih jelasnya, temuan tindak lanjut LHA dapat dilihat pada gambar dibawah ini.

Gambar 1.1. Status Laporan Hasil Audit pada Inspektorat Kementerian

Kesehatan RI tahun 2014

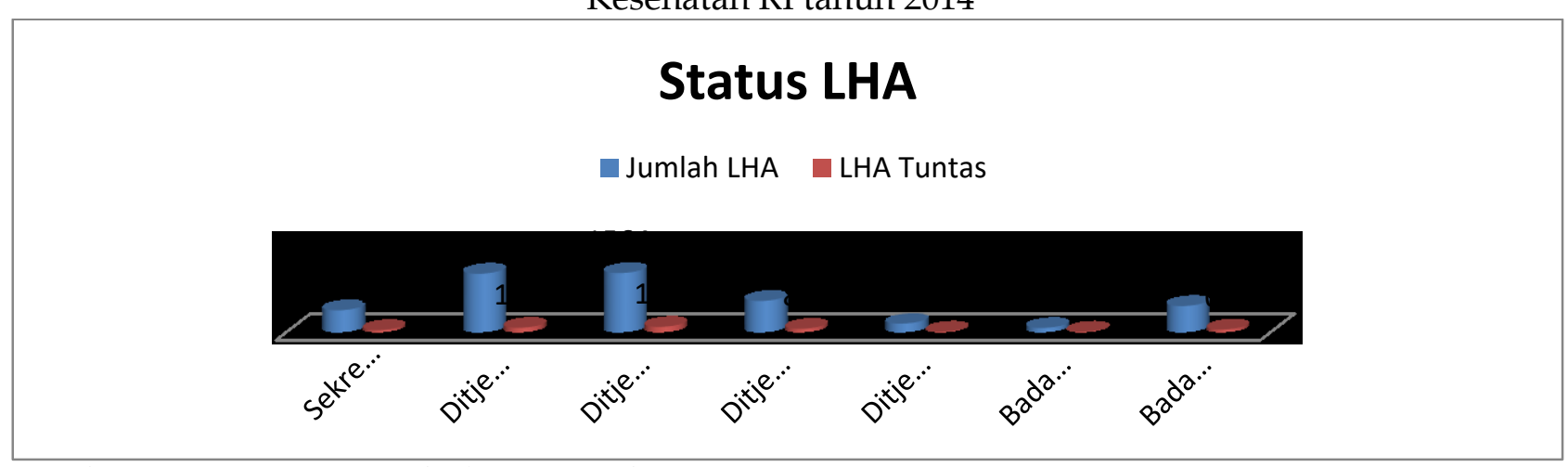

Sumber: Bagian APTLHP bulan Desember 2014

Gambar 1.2. Status Temuan Hasil Audit pada Inspektorat Kementerian

Kesehatan RI tahun 2014

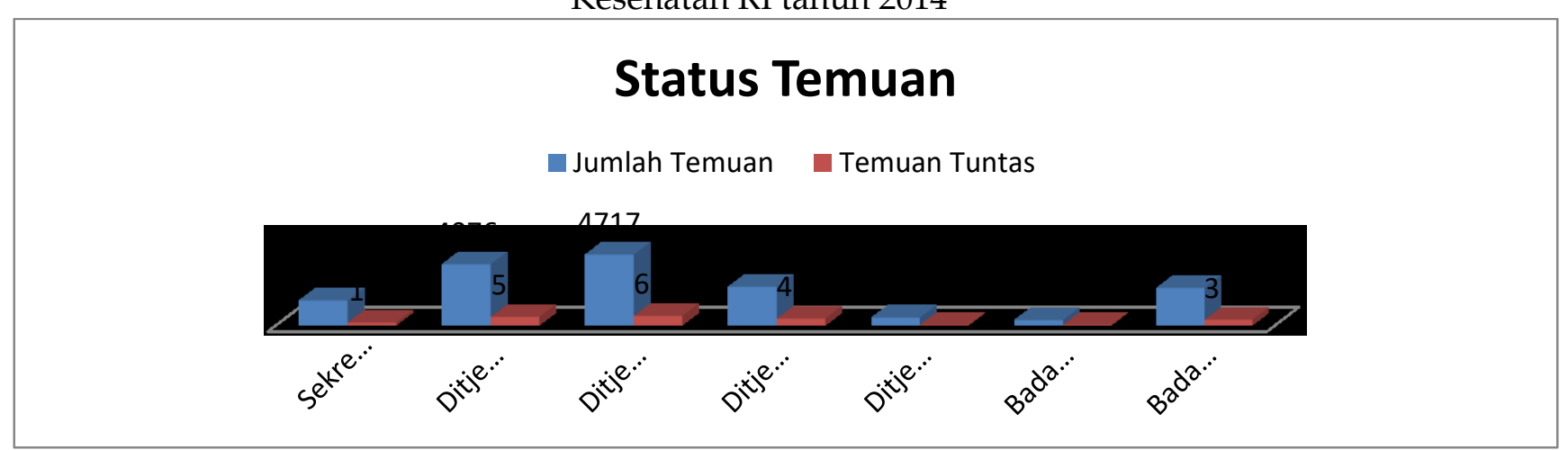

Sumber: Bagian APTLHP bulan Desember 2014

Gambar 1.3. Status Saran Hasil Audit pada Inspektorat Kementerian Kesehatan RI tahun 2014

\section{Status Saran}

u Jumlah Saran $\quad$ Saran Tuntas
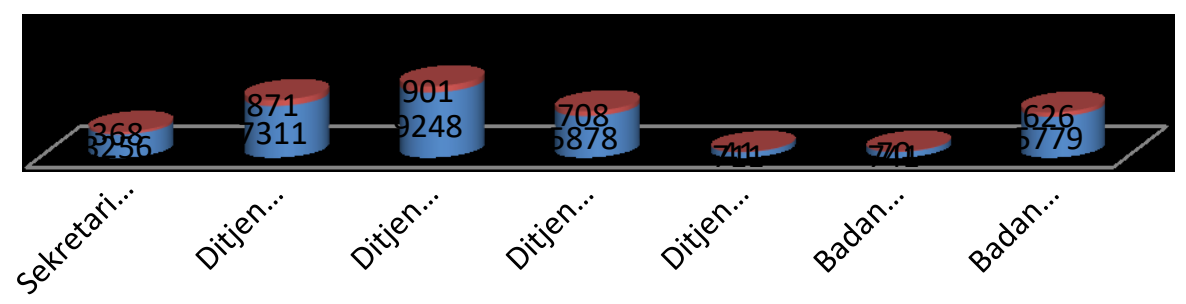

Sumber: Bagian APTLHP bulan Desember 2014

Rendahnya persentase tindak lanjut hasil merupakan salah satu indikasi bahwa kualitas audit yang dilakukan oleh auditee terse-but, audit yang dilakukan oleh In-spektorat 
Jenderal Kementerian Kesehatan RI tersebut masih belum optimal.

Berkualitas atau tidaknya pekerjaan auditor akan mempengaruhi kesimpulan akhir auditor dan secara tidak langsung juga akan mempengaruhi tepat atau tidaknya keputusan yang akan diambil oleh pihak luar perusahaan. Sehingga auditor dituntut harus memiliki rasa kebertanggungjawaban (akuntabilitas) dalam setiap melaksanakan pekerjaanya dan memliki sikap profesional, agar dapat mengurangi pelanggaran atau penyimpangan yang dapat terjadi pada proses pengauditan, sehingga akuntabilitas dan profesionalisme merupakan elemen penting yang harus dimiliki oleh seorang auditor.

Dari hasil pemetaan kapabilitas APIP 20102011 terhadap 331 APIP Pusat dan daerah menunjukan secara nasional sebesar $93 \%$ APIP masih berada di level 1 (initial), sedangkan 7\% berada pada level 2 (infrastructure). Level satu menggambarkan bahwa APIP belum dapat memberikan ja-minan atas proses tata kelola sesuai peraturan dan belum dapat mencegah korupsi. Level dua menggambarkan bahwa APIP mampu menjamin proses tata kelola sesuai dengan peraturan dan mampu mendeteksi terjadinya korupsi dan level tiga menggambarkan bahwa APIP mampu menilai efisiensi, efektivitas, ekonomis suatu kegiatan dan mampu mem-berikan konsultasi pada tata kelola, mana-jemen risiko, dan pengendalian intern. (BPKP:2011:11)

Rendahnya kapabilitas APIP ini disebabkan karena (1) Independensi dan objektivitas APIP belum dapat diterapkan sepenuhnya, (2) Lemahnya manajemen/tata laksana/bisnis proses APIP, (3) Tidak terpenuhinya kebutuhan formasi Auditor (4) Kurangnya alokasi anggaran belanja APIP dibandingkan dengan total belanja dalam APBN/APBD, (5) Struktur organisasi dan pola hubungan kerja belum sepenuhnya sesuai dengan strategi dalam mencapai tujuan APIP yang efektif, (6) Kurangnya kegiatan pengembangan kompetensi dan lemahnya manajemen SDM APIP terutama rekrutmen dan pola karier dan (7) Organisasi profesi auditor belum terbentuk sehingga standar audit, kode etik, dan peer review belum sepenuhnya tersedia dan belum dapat dilaksanakandengan efektif.

Sebagai auditor yang merupakan ujung tombak dari pelaksanaan kegiatan pemeriksaan seharusnya didukung dengan pengalaman kerja yang memadai dalam pemeriksaan, sikap independensi yang tinggi, kompetensi yang dimiliki oleh seorang auditor juga harus didukung oleh pengetahuan dan kemampuan yang handal untuk melaksanakan tugasnya, disertai dengan sikap Due Professional Care.

De Angelo (1981) yang menyatakan bahwa kualitas audit ditentukan oleh tingkat pengalaman dan independensi auditor. Tingkat pengalaman auditor menggambarkan kemampuan auditor untuk memahami lingkungan bisnis klien yang akan berguna untuk menilai kesesuaian dengan standar yang berlaku maupun tingkat kewajaran informasi keuangan.

Martani, dkk (2013) menyimpulkan bahwa pengalaman kerja dan kecermatan professional audit berpengaruh signifikan terhadap kualitas hasil pemeriksaan. Hal ini menunjukan hasil bahwa secara langsung pengalaman kerja secara parsial berpengaruh terhadap Kualitas hasil pemeriksaan artinya bahwa semakin banyak pengalaman kerja seorang auditor maka akan semakin mempengaruhi kinerjanya.

Kecermatan sebagaimana yang dinyatakan dalam SA-APIP adalah kecerma-tan profesional yaitu auditor harus menggunakan keahlian profesionalnya dengan cermat dan seksama (due profesional care) dan secara hatihati (prudent) dalam setiap penugasan. Due professional care dapat diterapkan dalam pertimbangan profesional (professional judgement), meskipun dapat saja terjadi penarikan kesimpulan yang tidak tepat ketika audit sudah dilakukan dengan seksama.

Dalam pelaksanaan tugas-tugas au-dit, Due Professional Care penting diterap-kan oleh auditor. Dalam hal ini auditor di-tuntut untuk selalu berpikir kritis, cermat dan seksama terhadap bukti-bukti audit yang telah 
ditemukan, demi tercapainya kualitas pemeriksaan audit yang baik dan berkualitas.

Penelitian Dea Arisanti dkk (2013) menyimpulkan bahwa due professional care berpengaruh signifikan terhadap kualitas audit serta penelitian Nirmala dan Cahyonowati (2013) memberikan bukti empiris bahwa Independensi, pengalaman Due professional care dan akuntabilitas berpengaruh signifikan positif terhadap kualitas audit. Hal ini berarti bahwa makin tinggi auditor yang dapat mengimplementasikan due professional care dalam pekerjaan auditnya dengan baik, maka hasil audit yang dihasilkan akan makin berkualitas.

Penelitian Wilasita dkk (2014) memberikan bukti empiris bahwa secara par-sial independensi, due professional care, kepatuhan pada kode etik berpengaruh signifikan terhadap kualitas hasil pemeriksaan audit dan secara simultan independensi, due professional care dan kepatuhan pada kode etik berpengaruh signifikan terhadap kualitas hasil pemeriksaan audit.

Penelitian Louwers dkk. (2008) da-lam Martini (2011) yang menyimpulkan bahwa kegagalan audit dalam kasus fraud transaksi pihak-pihak terkait disebabkan ka-rena kurangnya sikap skeptis dan due profes-sional care auditor daripada kekurangan da-lam standar auditing.

Selain kecermatan dalam melakukan kegiatan audit, akuntabilitas seorang auditor sangat diharapkan. Akuntabilitas menunjukkan kemampuan dari seorang auditor dalam menjalankan dan melaksanakan tanggung jawab sebagai seorang auditor, semakin tinggi akuntabilitas yang dimiliki auditor akan meningkatkan kualitas audit yang dihasilkan.

Andi Yahya Sembiring (2011) menyatakan bahwa kualitas dari hasil peker-jaan auditor dapat dipengaruhi oleh rasa kebertanggungjawaban (akuntabilitas) yang dimiliki auditor dalam menyelesaikan pekerjaan audit. Akuntabilitas merupakan dorongan psikologi sosial yang dimiliki seseorang untuk menyelesaikan kewajibannya yang akan dipertanggungjawabkan kepada lingkungannya dan penelitian Sarpudin dkk
(2012) menunjukan bahwa baik secara simultan maupun parsial independensi, pengalaman, due professional care dan akuntabilitas memiliki pengaruh yang positif dan signifikan terhadap kualitas audit. Nirma-la dkk (2013) dalam penelitiannya tentang faktor-faktor yang mempengaruhi kualitas audit, menyimpulkan bahwa Independensi, Pengalaman, due professional care, dan akuntabilitas, berpengaruh signifikan positif terhadap kualitias audit, selain itu Subhan menyimpulkan bahwa secara simultan latar belakang pendidikan, kompetensi tehnis, pendidikan dan pelatihan berkelanjutan, pengalaman kerja, kecermatan profesi, obyektifitas, indepedensi dan kepatuhan pada kode etik secara mempengaruhi kualitas hasil pemeriksaan.

Pengalaman kerja yang memadai, kompetensi yang dimiliki seorang auditor, serta sikap Due Professional care juga merupakan hal penting dalam fungsi pelaksanaan pemeriksaan. Hal ini penting, karena selain mematangkan pertimbangan salama penyusunan laporan hasil pemeriksaan juga diharapkan untuk dapat mencapai harapan pemerintah yang bersih dan transparan.

\section{TELAAH TEORI PENGEMBANGAN HIPOTESIS \\ Teori Kebutuhan McClelland}

DAN

a. Kebutuhan akan prestasi,

b. Kebutuhan akan kekuasaan,

c. Kebutuhan akan afiliasi,

\section{Teori ERG}

a. E (Existence atau keberadaan)

b. R (Relatedness atau hubungan)

c. $\mathrm{G}$ (Growth atau pertumbuhan)

\section{Auditing}

Auditing adalah pengumpulan dan evaluasi bukti tentang informasi untuk menentukan dan melaporkan derajat kesesuaian antara informasi itu dan kriteria yang telah ditetapkan. Auditing harus dilakukan oleh orang yang kompeten dan independen. Sedangkan kegiatan membandingkan sutau kriteria (apa yang seharusnya) dengan kondisi (apa yang sebenarnya terjadi). 
Jenis Audit

1. Audit Keuangan

2. Audit Kinerja

3. Audit dengan Tujuan Tertentu

Audit Sektor Publik

1. Perencanaan

2. Pelaksanaan

3. Pelaporan

Standar Audit APIP terdiri dari:
a. Prinsip-prinsip Dasar
b. Standar Umum
c. Standar Pelaksanaan Audit Kinerja
d. Standar Pelaporan Audit Kinerja
e. Standar Tindak Lanjut Audit Kinerja

\section{Kualitas Audit}

Beberapa definisi tentang kualitas audit yaitu 1) Probabilitas bahwa auditor akan baik dan benar menemukan laporan kesalahan material, keliru, atau kelalaian dalam laporan keuangan yang material, 2) Probabilitas bahwa auditor tidak akan mengeluarkan laporan wajar tanpa pengecualian untuk laporan yang mengandung kesalahan material (Lee et al, 1999 dalam Baotham et al., 2009), 3) Ketepatan pelaporan informasi auditor (Davidson dan Neu, 1993), dan 4) Mengukur kemampuan audit untuk mengurangi kebisingan dan bias dan meningkatkan ketelitian dalam data akuntansi (Wallace, 1980 dalam Baotham et al., 2009).

\section{Pengalaman}

Semakin sering auditor bekerja dan melakukan pekerjaan yang sama, maka akan menjadi makin terampil auditor tersebut dalam menyelesaikan pekerjaannya. Auditor yang tidak berpengalaman akan melakukan kesalahan yang lebih banyak dibanding dengan auditor yang berpengalaman. Semakin banyak macam pekerjaan yang dilakukan seseorang, pengalaman kerjanya akan semakin kaya dan luas, dan memungkinkan peningkatan kinerja.

\section{Due Professional Care}

BPKP (2007) menyatakan bahwa Due professional care dalam auditing adalah upaya maksimal dari setiap auditor dalam pemanfaatan pengetahuan, keterampilan, dan pertimbangan rasional dengan penuh kehatihatian dalam melaksanakan fungsi auditing, termasuk dalam hal merencanakan, mengarahkan, dan mengendalikan kegiatan pembuktian, serta dalam hal pengambilan simpulan, sehingga kewajiban yang dibebankan kepadanya dapat dipertanggungjawabkan secara profesional.

Auditor perlu mengenali berbagai sumber pengetahuan tentang objek informasi yang diauditnya, Montague dalam The Ways of Knowing (MacMilan, 1953), yakni: a)Authoritarianism, yaitu pengetahuan yang didasarkan pada keyakinan terhadap sumbernya karena tingkat persuasinya yang memadai, misalnya konfirmasi, rekening koran, atau pendapat ahli. b)Mysticism, yaitu pengetahuan yang didasarkan pada intuisi, imajinasi, atau pengalaman, seperti dalam hal auditor melakukan scanning atau reviu analitis. c)Rationalism, yaitu pengetahuan yang didasarkan pada kemampuan berpikir secara logis, sebagaimana dipraktekkan oleh auditor ketika melakukan analisis matematik. d)Empiricism, yaitu pengetahuan yang diperoleh berdasarkan data yang dihimpun langsung, seperti yang diperoleh melalui pembuktian dengan pemeriksaan fisik dan pengamatan dokumen. e)Pragmatism, yaitu pengetahuan yang didasarkan pada kenyataan tentang apa yang betul-betul berlangsung dengan efektif, seperti terjadi dalam hal auditor mengestimasi kelayakan kolektibiltas piutang.

\section{Akuntabilitas}

Akuntabilitas ("accountability") memiliki arti pertanggungjawaban atau keadaan untuk dipertanggungjawabkan atau keadaan untuk diminta pertanggungjawaban. Tetlock (1984) dalam Saripudin (2012), mendefinisikan akuntabilitas sebagai bentuk dorongan psikologi yang membuat seseorang berusaha mempertanggungjawabkan semua tindakan dan keputusan yang diambil kepada lingkungannya.

BPKP (2007) menyatakan bahwa akuntabilitas bearti wujud 
pertanggungjawaban seseorang atau unit organisasi, dalam mengelola sumber daya yang telah diberikan dan dikuasai, dalam rangka pencapaian tujuan, melalui suatu media berupa laporan akuntabilitas kinerja secara periodik. Selain itu akuntabilitas juga sebagai kewajiban untuk menjawab dan menjelaskan kinerja dari tindakan seseorang atau badan kepada pihakpihak yang memiliki hak untuk meminta jawaban atau keterangan dari orang atau badan yang telah diberikan wewenang untuk mengelola sumber daya tertentu.

\section{Pengembangan Hipotesis}

\section{Pengaruh Pengalaman Terhadap Kualitas Audit}

Audit menuntut keahlian dan profesionalitas yang tinggi. Keahlian tidak hanya diperoleh dari pendidikan formal, tetapi banyak faktor lain yang mempengaruhinya, seperti pengalaman. Pengalaman merupakan suatu proses pembelajaran dan penambahan perkembangan potensi bertingkah laku baik dari pendidikan formal maupun non formal atau bisa juga diartikan sebagai suatu proses yang membawa seseorang kepada suatu pola tingkah laku yang lebih tinggi. (Knoers dan Haditono;1999) dalam Martani (2013). Dari hasil penelitian yang dilakukan oleh Martani, dkk (2013), Nirmala (2013), Nugraha (2013), Saripudin, dkk (2013) yang menyimpulkan bahwa pengalaman kerja berpengaruh signifikan terhadap kualitas hasil audit, namun penelitian lain yang dilakukan oleh Singgih (2010), Badjuri (2012) dan Arisanti, dkk (2013) mendapatkan hasil bahwa pengalaman tidak berpengaruh terhadap kualitas audit. H1: Ada pengaruh yang signifikan antara pengalaman auditor terhadap kualitas audit.

\section{Pengaruh Due Professional Care Terhadap Kualitas Audit}

Due professional care dalam auditing berarti upaya maksimal dari setiap auditor dalam pemanfaatan pengetahuan, keterampilan, dan pertimbangan rasional dengan penuh kehati-hatian dalam melaksanakan fungsi auditing, termasuk dalam hal merencanakan, mengarahkan, dan mengendalikan kegiatan pembuktian, serta dalam hal pengambilan simpulan, sehingga kewajiban yang dibebankan kepadanya dapat dipertanggungjawabkan secara profesional (BPKP 2007)

Due professional care memiliki arti kemahiran profesional yang cermat dan seksama. Menurut PSA No. 4 SPAP (2001), kecermatan dan keseksamaan dalam penggunaan kemahiran profesional menuntut auditor untuk melaksanakan skeptisme profesional, yaitu suatu sikap auditor yang berpikir kritis terhadap bukti audit dengan selalu mempertanyakan dan melakukan evaluasi terhadap bukti audit tersebut. Penggunaan kemahiran profesional dengan cermat dan seksama memungkinkan auditor untuk memperoleh keyakinan memadai bahwa laporan keuangan bebas dari salah saji material, baik yang disebabkan oleh kekeliruan maupun kecurangan.

Dari hasil penelitian yang dilakukan oleh Martini, dkk (2011), Saripudin, dkk (2012), Arisanti, dkk (2013), Nirmala (2013), Nugraha (2013), dan Wilasita (2014) yang menyimpulkan bahwa Due professional care berpengaruh positif terhadap kualitas audit. H2: Ada pengaruh yang signifikan antara due professional care terhadap kualitas audit.

\section{Pengaruh Akuntabilitas Terhadap Kualitas Audit}

Tetlock (1984) dalam Saripudin (2012), mendefinisikan akuntabilitas sebagai bentuk dorongan psikologi yang membuat seseorang berusaha mempertanggungjawabkan semua tindakan dan keputusan yang diambil kepada lingkungannya. Kualitas hasil pekerjaan auditor dapat dipengaruhi oleh rasa kebertanggungjawaban (akuntabilitas) yang dimiliki auditor dalam menyelesaikan pekerjaannya. BPKP (2007) menyatakan bahwa akuntabilitas bearti sebagai perwujudan pertanggungjawaban seseorang atau unit organisasi, dalam mengelola sumber daya yang telah diberikan dan dikuasai, dalam rangka pencapaian tujuan, melalui suatu media berupa laporan akuntabilitas kinerja secara periodik. 
Selain itu akuntabilitas juga sebagai kewajiban untuk menjawab dan menjelaskan kinerja dari tindakan seseorang atau badan kepada pihakpihak yang memiliki hak untuk meminta jawaban atau keterangan dari orang atau badan yang telah diberikan wewenang untuk mengelola sumber daya tertentu.

Dari hasil penelitian yang dilakukan oleh Martini, dkk (2011), Sembiring (2011), Saripudin, dkk (2012), Arisanti, dkk (2013), dan Nirmala (2013), menyimpulkan bahwa akuntabilitas berpengaruh positif terhadap kualitas audit. H3: Ada pengaruh yang signifikan antara akuntabilitas terhadap

\section{kualitas audit.}

Berdasarkan konsep dan teori sebagaimana diuraikan sebelumnya, maka dibangun kerangka pemikiran yang dapat digunakan sebagai paradigma penelitian yang bertujuan untuk melihat pengaruh pengalaman, due professional care dan akuntabilitas terhadap kualitas hasil audit yang dapat digambarkan sebagai berikut, H4: Ada pengaruh yang signifikan antara pengalaman auditor, due professional care dan akuntabilitas terhadap kualitas audit :

Gambar 2.1.

Rerangka Pemikiran Teoritis

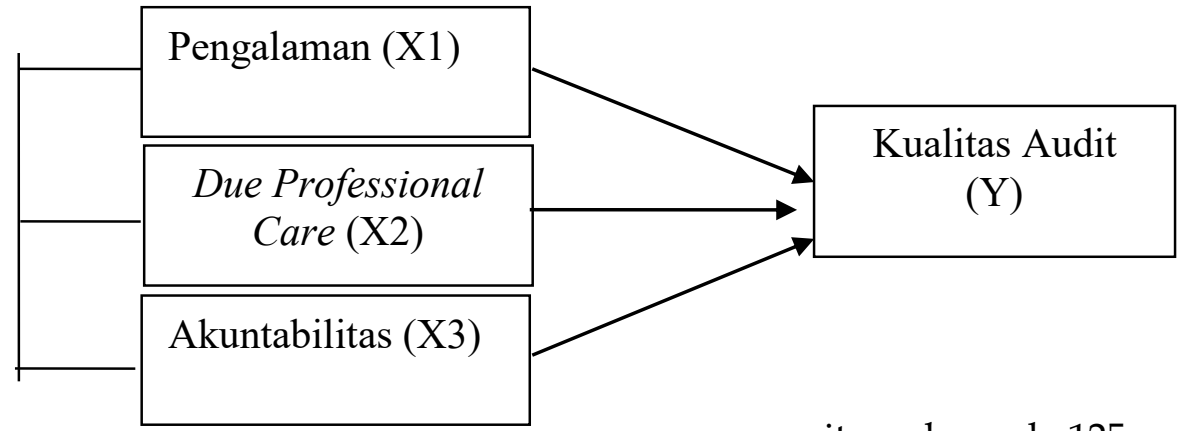

yaitu sebanyak 125 orang dengan klasifikasi jabatan auditor madya, auditor muda, dan

\section{METODE PENELITIAN}

\section{Jenis dan Sumber Data}

Jenis data dalam penelitian adalah data kualitatif, merupakan penelitian yang datanya berbentuk angka atau data kualitatif yang diangkakan/scoring.

Sumber data dalam penelitian ini adalah data primer (utama) dan sekunder (sebagai alat penunjang hasil penelitian).

\section{Metode Pengumpulan Data}

Metode pengumpulan data dalam penelitian ini adalah dengan cara membagikan kuesioner yang berisi daftar pernyataan tertulis kepada responden agar responden tersebut memberikan jawabannya.

\section{Populasi dan Sampel Penelitian}

Populasi yang digunakan dalam penelitian ini adalah seluruh auditor pada Inspektorat Jenderal Kementerian Kesehatan RI auditor pertama.

Rekapitulasi Jumlah Auditor Pada Inspektorat Jenderal Kementerian Kesehatan RI Tahun 2014

\begin{tabular}{|c|l|c|}
\hline No. & Jenjang Jabatan Auditor & Populasi \\
\hline 1 & Auditor Madya & 12 \\
\hline 2 & Auditor Muda & 50 \\
\hline 3 & Auditor Pertama & 63 \\
\hline \multicolumn{2}{|c|}{ Jumlah } & 125 \\
\hline
\end{tabular}

Sumber data: Bagian Kepegawaian Kemekes RI (Nopember 2014)

\section{Teknik Sampling}

Untuk membuat generalisasi hasil penelitian sampel, maka sampel yang digunakan harus mewakili populasi. Pengambilan sampel yang dapat mewakili populasi adalah dengan teknik random 
sampling. Pengambilan sampel dalam penelitian ini adalah Disproportionate Stratified Random Sampling.

\section{Ukuran Sampel}

Jumlah sampel sering dinyatakan dengan ukuran sampel. Jumlah sampel yang diharapkan adalah dapat mewakili populasi, sehingga tidak terjadi kesalahan generalisasi. Untuk menghitung jumlah sampel dalam penelitian ini dengan menggunakan rumus Slovin.

$$
n=\frac{N}{1+N e^{2}}
$$

$\mathrm{n}=$ Jumlah sampel

$\mathrm{N}=$ Populasi

e $=$ Margin $/$ Sampling Error

Berdasarkan rumus slovin diatas, maka jumlah sampel dalam penelitian ini, yaitu :

$$
n=\frac{125}{1+\left(125 \times 0,05^{2}\right)}
$$

$n=95$

\section{Uji Validitas Instrumen}

\section{Uji Validitas}

Uji validitas digunakan untuk mengukur sah atau tidaknya suatu kuesioner, dilakukan dengan cara membandingkan $r$ hitung dengan $\mathrm{r}$ tabel, dengan tingkat signifikansi $5 \%$.

\section{Uji Reliabilitas}

Uji reliabilitas dilakukan dengan tujuan untuk mengetahui konsistensi derajat ketergantungan dan stabilitas alat ukur. Kuesioner dikatakan reliabel atau handal jika jawaban seseorang terhadap pertanyaan adalah konsisten atau stabil dari waktu ke waktu.

\section{Definisi dan Operasionalisasi Variabel}

\section{Variabel Independen $(X)$}

Variabel independen (bebas) merupakan variabel yang menjelaskan atau mempengaruhi variabel lain. Variabel independen dalam penelitian ini, yaitu pengalaman, due professional care, dan akuntabilitas.

\section{Pengalaman (X1)}

Pengalaman merupakan suatu proses pembelajaran dan pertambahan perkembangan potensi bertingkah laku, baik dari pendidikan formal maupun informal, atau dapat diartikan sebagai suatu proses yang membawa seseorang kepada suatu polah tingkah laku yang lebih tinggi (Knoers dan Haditono dalam saripudin, 2012). Untuk mengukur variabel pengalaman dalam penelitian ini, digunakan instrumen yang dikembangkan oleh Mas'ud (2014). Pada variabel ini digunakan 7 item pertanyaan yang diukur dengan 5 poin skala Likert.

\section{Due Professional Care(X2)}

Due professional care adalah kemahiran profesional yang cermat dan seksama. Menurut PSA No. 4 SPAP (2001), kecermatan dan keseksamaan dalam penggunaan kemahiran profesional menuntut auditor untuk melaksanakan skeptisme profesional, yaitu suatu sikap auditor yang berpikir kritis terhadap bukti audit dengan selalu mempertanyakan dan melakukan evaluasi terhadap bukti audit tersebut. Pada variabel ini digunakan 7 item pertanyaan yang diukur dengan 5 poin skala Likert.

\section{Akuntabilitas (X3)}

Akuntabilitas yaitu pertanggungjawaban atau keadaan untuk dipertanggungjawabkan atau keadaan untuk diminta pertanggungjawaban. Akuntabilitas sebagai bentuk dorongan psikologi yang membuat seseorang berusaha mempertanggungjawabkan semua tindakan dan keputusan yang diambil kepada lingkungannya (Tetlock (dalam saripudin: 2012). Pada variabel ini digunakan 7 item pertanyaan yang diukur dengan 5 poin skala Likert. 


\section{Variabel Dependen (Y)}

Variabel dependen dalam penelitian ini yaitu kualitas audit. Kualitas audit merupakan Gabungan dari dua dimensi, yaitu dimensi proses dan dimensi hasil. Dimensi proses adalah bagaimana pekerjaan audit dilaksanakan oleh auditor dengan ketaatannya pada standar yang ditetapkan. Dimensi hasil adalah bagaimana keyakinan yang meningkat yang diperoleh dari laporan audit oleh pengguna laporan keuangan (Sutton dalam Nugraha : 2013) Pada variabel ini digunakan 7 item pertanyaan yang diukur dengan 5 poin skala Likert.

\section{Metode Analisa Data}

Untuk menguji hubungan antara satu variabel terikat dan lebih dari satu variabel bebas digunakan metode statistik yaitu dengan metode regresi berganda. Secara matematis rumus regresi berganda sebagai berikut:

$\mathrm{Y}=\mathrm{a}+\mathrm{b} 1 \mathrm{X} 1+\mathrm{b} 2 \mathrm{X} 2+\mathrm{b} 3 \mathrm{X} 3+\mathrm{e}$

Keterangan:

a : Konstanta

Y : Variabel dependen (kualitas audit)

X1 : Variabel independen (pengalaman auditor)

X2 : Variabel independen (due professional care)

X3 : Variabel independen (akuntabilitas)

e (Epselon) : Variabel lain yang mempengaruhi

Analisa data yang akan digunakan yaitu dengan menggunakan software SPSS (Statistical Package for Social Science) 21.0 yang meliputi :

\section{Pengujian Hipotesis}

\section{Uji Regresi secara Simultan (Uji F)}

Uji F (Fisher) merupakan suatu pengujian untuk mengetahui besarnya pengaruh varibelvaribel independen terhadap variabel dependens secara bersama-sama. Untuk itu, maka hipotesis statistiknya adalah :

1) $H_{0}: \beta_{1}=0:$ tidak ada pengaruh

2) $\mathrm{H}_{1}: \beta_{1} \pm 0:$ ada pengaruh
Dengan menentukan taraf signifikan $(\alpha=0,05$ atau $5 \%$ ), maka nilai $\mathrm{F}$ hitung dapat ditentukan dengan mengunakan rumus :

$$
F=\frac{R^{2} /(k-1)}{\left(I-R^{2}\right) /(n-k)}
$$

\section{Keterangan :}

$\mathrm{F}=$ Nilai kemaknaan seluruh variabel

$\mathrm{R}^{2}=$ Koefisien determinasi

$\mathrm{K}$ = Banyaknya variabel bebas

$\mathrm{N}=$ Jumlah sample (observasi)

Ada tidaknya pengaruh variabel independen secara simultan terhadap variabel dependen secara signifikan dilakukan dengan melihat probabilitas F hitung (nilai Sig F) dari seluruh variabel bebas pada taraf uji $a=5 \%$ $(0,05)$. Kesimpulan diterima atau ditolaknya $\mathrm{H} 0$ dan H1 sebagai pembuktian adalah:

\section{Uji Regresi secara Parsial (Uji t)}

Uji $t$ adalah pengujian untuk mengetahui besarnya pengaruh masingmasing variabel independen terhadap variabel dependen. Untuk itu, maka hipotesis statistiknya adalah :

1) $H_{0}$ : salah satu $\beta_{1}, \beta_{2}$ atau $\beta_{3}=0$ : tidak ada pengaruh

2) $H_{1}$ : salah satu $\beta_{1}, \beta_{2}$ atau $\beta_{3} \neq 0$ : ada pengaruh

Dengan menggunakan taraf signifikan $(\alpha=5$ $\%)$. Maka nilai $t$ hitung dapat diketahui dengan menggunakan rumus :

$$
t_{\text {hitung }}=\frac{a 1}{\operatorname{Se} \cdot a 1}
$$

\section{Keterangan : \\ $a_{1}=$ Koefisien regresi varibel ke -1 \\ $\mathrm{Se}=$ Standar error}

Signifikan tidaknya pengaruh variabel independen secara simultan terhadap variabel dependen dilakukan dengan melihat probabilitas $\mathrm{t}$ hitung (nilai Sig $\mathrm{t}$ ) dari masingmasing variabel bebas pada taraf uji $a=5 \%$ 
$(0,05)$. Kesimpulan diterima atau ditolaknya H0 dan $\mathrm{H} 1$ sebagai pembuktian adalah:

\section{Koefisien Determinasi}

Untuk melihat besarnya kemampuan variabel independen sebagai prediktor untuk menjelaskan variabel dependen digunakan Uji koefisien.

Perhitungan nilai koefisien determinasi ini menurut Algifari (2000 : 48) diformulasikan sebagai berikut :

$R^{2}=\frac{E S S}{T S S}$

Di mana :

1) $\mathrm{R}^{2}=$ Koefisien determinasi majemuk (multiple coefficient) of determination ) yaitu prioritas variabel terikat yang dapat dijelaskan oleh variabel secara bersamasama.

2) ESS = Explained Sum of Squares atau jumlah kuadrat yang dijelaskan atau variasi nilai variabel terikat yang ditaksir sekita rata-rata.

3) TSS = Total Sum of Squares, atau total variasi nilai varibel terikat sebenarnya disekitar rata-rata.

\section{HASIL DAN PEMBAHASAN Statistik Diskriptif}

Untuk mengetahui gambaran atau deskripsi data penilitian ini maka dapat dilihat dari nilai rata-rata (mean), standar deviasi, maksimum, dan minimum, dari masingmasing variabel, terlihat pada tabel berikut:

Tabel 4.1.

Statistik Deskriptif Variabel

\begin{tabular}{|l|c|c|c|c|c|}
\hline \multicolumn{1}{|c|}{ Variabel } & N & $\begin{array}{c}\text { Minimu } \\
\mathrm{m}\end{array}$ & $\begin{array}{c}\text { Maximu } \\
\mathrm{m}\end{array}$ & Mean & $\begin{array}{c}\text { Std } \\
\text { Deviation }\end{array}$ \\
\hline Pengalaman & 89 & 16 & 23 & 18,70 & 2,122 \\
\hline Due Professional Care & 89 & 20 & 25 & 22,44 & 1,678 \\
\hline Akuntabilitas & 89 & 17 & 22 & 18,96 & 1,086 \\
\hline Kualitas Audit & 89 & 24 & 29 & 26,55 & 1,645 \\
\hline
\end{tabular}

Sumber : Hasil pengolahan data

Dari hasil output spps diatas diketahui untuk variabel pengalaman dengan jumlah responden sebanyak 89 orang, dengan nilai minimum sebesar 16, nilai maksimum sebesar 23. Rata-rata nilai untuk variabel pengalaman sebesar 18,70 dengan standar deviasi sebesar 2,122.

Variabel Due Professional Care memiliki jumlah responden sebanyak 89 orang nilai minimum sebesar 20, nilai maksimum sebesar 25, dan rata-rata nilai Due Professional Care sebesar 22,44 dengan standar deviasi sebesar 1,678. Untuk variabel Akuntabilitas dengan responden sebanyak 89 orang, nilai minimum sebesar 19, nilai maksimum sebesar 22, dan rata-rata sebesar 18,96 dengan standar deviasi sebesar 1,086. Dan untuk variabel kualitas audit responden sebanyak 89 orang, nilai minimum sebesar 24, nilai maksimum sebesar 29, rata-rata nilai sebesar 26,55 dengan standar deviasi sebesar 1,645.

\section{Pembahasan Hasil Penelitian}

Berdasarkan hasil output SPSS yang telah dilakukan untuk mengolah data dalam penelitian ini, maka hasil pembahasan sebagai berikut:

\section{Pengaruh Pengalaman, Due Professional Care dan Akuntabilitas Terhadap Kualitas Audit.}

Hasil penelitian menunjukkan bahwa $\mathrm{H} 0$ ditolak dan $\mathrm{H} 1$ diterima. Hal ini berarti bahwa pengalaman, due professional care dan akuntabilitas secara simultan berpengaruh terhadap kualitas audit.

Dari ketiga variabel bebas tersebut ternyata variabel due professional care memiliki pengaruh yang paling besar terhadap kualitas audit, kemudian variabel yang kedua adalah akuntabilitas. Sementara pengalaman secara parsial tidak berpengaruh signifikan terhadap kualitas audit. 


\section{Pengaruh Pengalaman Terhadap Kualitas Audit}

Hasil uji parsial menunjukkan bahwa pengalaman tidak mempunyai pengaruh yang signifikan terhadap kualitas audit. Hasil pengujian statististik tersebut menunjukan bahwa pengalaman auditor belum terlihat sebagai penunjang terhadap kualitas audit, dimana kualitas audit dapat dicapai apabila seseorang auditor memiliki pengalaman yang cukup.

Kebanyakan orang memahami bahwa semakin banyak jumlah jam terbang seorang auditor, tentunya dapat memberikan kualitas audit yang lebih baik daripada seorang auditor yang baru memulai kariernya. Atau dengan kata lain auditor yang berpengalaman diasumsikan dapat memberikan kualitas audit yang lebih baik dibandingkan dengan auditor yang belum berpengalaman. Hal ini dikarenakan pengalaman akan membentuk keahlian seseorang baik secara teknis maupun secara psikis.

Namun asumsi tersebut belum terlihat baik dari sisi jabatan fungsional auditor sebagai auditor muda sebanyak 55 auditor $(61,8 \%)$ maupun sebagai auditor pertama sebanyak 34 auditor (38,2\%). Begitu pula bila dilihat dari lamanya auditor bekerja, sebanyak 28 auditor $(31,5 \%)$ bekerja selama 7 8 tahun dan sebanyak 23 orang $(25,8 \%)$ auditor yang bekerja lebih dari 8 tahun.

Hasil penelitian ini tidak sejalan dengan penelitian yang dilakukan oleh Martani, dkk (2013), Nirmala (2013), Nugraha (2013), Saripudin, dkk (2013) yang menyimpulkan pengalaman kerja berpengaruh signifikan terhadap kualitas hasil audit. Namun penelitian ini sejalan dengan penelitian yang dilakukan oleh Singgih (2010), Badjuri (2012) dan Arisanti, dkk (2013) yang menyimpulkan bahwa pengalaman tidak berpengaruh terhadap kualitas audit. Dari kuesioner variabel pengalaman didapat hasil bahwa faktor pengalaman yang rendah menunjukan hasil belum maksimalnya kegiatan pelatihan dan seminar oleh para auditor.

\section{Pengaruh Due Professional Care Terhadap Kualitas Audit}

Hasil uji parsial menunjukkan bahwa due professional care mempunyai pengaruh yang signifikan terhadap kualitas audit. Kualitas audit dapat dicapai dengan due professional care yang tinggi.

Dalam Standar Umum ketiga (SA Seksi SPAP, 2011) menyatakan bahwa dalam pelaksnaan audit dan penyusunan laporannya, auditor wajib menggunakan kemahiran profesionalnya dengan cermat dan seksama. Standar ini menghendaki auditor independen untuk cermat dan seksama dalam menjalankan tugasnya. Begitu juga dalam standar umum keempat (Permenpan

Nomor: PER/05/M.PAN/03/2008) menyatakan bahwa kecermatan profesional auditor harus menggunakan keahlian profesionalnya dengan cermat dan seksama (due professional care) dan secara hati-hati (prudent) dalam setiap penugasan

Hasil penelitian ini sejalan dengan penelitian yang dilakukan oleh Martini, dkk (2011), Saripudin, dkk (2012), Arisanti, dkk (2013), Nirmala (2013), Nugraha (2013), dan Wilasita (2014) yang menyimpulkan bahwa Due professional care berpengaruh positif terhadap kualitas audit.

\section{Pengaruh Akuntabilitas Terhadap Kualitas Audit}

Hasil uji parsial menunjukkan bahwa akuntabilitas mempunyai pengaruh yang signifikan terhadap kualitas audit.

BPKP (2007) menyatakan bahwa akuntabilitas bearti sebagai perwujudan pertanggungjawaban seseorang atau unit organisasi, dalam mengelola sumber daya yang telah diberikan dan dikuasai, dalam rangka pencapaian tujuan, melalui suatu media berupa laporan akuntabilitas kinerja secara periodik. Selain itu akuntabilitas juga sebagai kewajiban untuk menjawab dan menjelaskan kinerja dari tindakan seseorang atau badan kepada pihak-pihak yang memiliki hak untuk meminta jawaban atau keterangan dari orang atau badan yang telah 
diberikan wewenang untuk mengelola sumber daya tertentu.

Menurut Tan dan Alison (1999) menyatakan bahwa seseorang dengan akuntabilitas tinggi memiliki keyakinan yang lebih tinggi bahwa pekerjaan mereka akan diperiksa oleh supervisor/manajer/pimpinan dibandingkan dengan seseorang yang memiliki akuntabilitas rendah.

Hasil penelitian ini sejalan dengan penelitian yang dilakukan oleh Martini, dkk (2011), Sembiring (2011), Saripudin, dkk (2012), Arisanti, dkk (2013), dan Nirmala (2013), menyimpulkan bahwa akuntabilitas berpengaruh positif terhadap kualitas audit.

\section{SIMPULAN}

Tidak terdapat pengaruh yang signifikan antara pengalaman terhadap kualitas audit secara parsial. Hal ini bearti jika pengalaman mengalami kenaikan satu satuan, maka akan meningkatkan kualitas audit sebesar 0,080 atau semakin banyak pengalaman auditor maka kualitas audit semakin baik.

Terdapat pengaruh yang signifikan antara due professional care terhadap kualitas audit secara parsial. Kualitas audit dapat dicapai dengan due professional care yang tinggi. Artinya bila auditor bekerja dengan cermat dan seksama satu satuan, maka akan meningkatkan kualitas audit sebesar 0,148

Terdapat pengaruh yang signifikan antara akuntabilitas terhadap kualitas audit secara parsial. Artinya jika akuntabilitas mengalami kenaikan satu satuan maka akan meningkatkan kualitas audit sebesar 0,313 atau semakin tinggi akuntabilitas seorang auditor maka kualitas audit semakin baik.

Terdapat pengaruh yang signifikan antara pengalaman, due professional care dan akuntabilitas terhadap kualitas audit secara simultan. Berdasarkan nilai adjusted $\mathrm{R}^{2}$ adalah sebesar 0,325 atau sebesar 32,5\% variasi dari ketiga variabel independen yaitu variabel pengalaman, due professional care dan akuntabilitas mampu menjelaskan variasi variabel dependen yaitu kualitas audit sedangkan sisanya yaitu sebesar 67,5 \% dipengaruhi oleh faktor lain di luar model penelitian ini.

\section{REFERENSI}

A. Basit. F.N., 2013, Pengaruh Pengalaman, Due Professional Care, dan Independensi Auditor Terhadap Kualitas Audit.

Arisanti. D, Dwi F. P, Herawati., 2013, Pengaruh Independensi, Pengalaman Kerja, Due Professional Care, Akuntabilitas dan Kompetensi Terhadap Kualitas Audit.

Ayu. I. P.W., Edy Sujana dan Lucy S.S., 2014, Pengaruh Independensi, Due Professional Care, dan Kepatuhan pada Kode Etik Terhadap Kualitas Hasil Pemeriksaan Audit, e-Jurnal S1 Ak Universitas Pendidikan Ganesha Jurusan Akuntansi Progam S1 Volume:2 No. 1 Tahun 2014

Hutabarat. G., 2011, Pengaruh Pengalaman, Time Budget Pressure, dan Etika Auditor terhadap Kualitas Audit, Jurnal Ilmiah ESAI Volume 6, Nomor 1, Januari 2012

Ghozali. I., 2013, SPSS 21 Aplikasi Analisis Multivariate Dengan Program SPSS, BP Universitas Diponegoro Edisi 7, Semarang

Martini. L, Bokiu. Z dan Pakaya. L., 2013, Pengaruh Kecermatan Professional dan Pengalaman Kerja Terhadap Kualitas Hasil Pemeriksaan.

Mayangsari. S dan Wandanarum. P ., 2013, Auditing: Pendekatan Sektor Publik dan Privat, Penerbit Media Bangsa, Jakarta.

Rr. Putri A.N dan Cahyonowati. N., 2013, Pengaruh Independensi, Pengalaman, Due Professional Care, Akuntabilitas, Kompleksitas Audit, dan Time Budget Pressure Terhadap Kualitas Audit, eJurnal Akuntansi Universitas Diponegoro Volume 2, Nomor 3, 
Tahun 2013.

Santoso. S., 2014, Statistik Multivariat, Edisi Revisi, Konsep dan Aplikasi dengan SPSS, Penerbit PT Elex Media Komputindo, Jakarta

Saripudin, Herawaty. N, dan Rahayu., 2012, Pengaruh Independensi, Pengalaman, Due Professional Care, dan Akuntabilitas Terhadap Kualitas Audit, e-Jurnal BINAR Akuntansi Vol.1 No.1, September 2012. ISSN 2303-1522

Sugiyono,2014, Cara Mudah Menyusun Skripsi, Tesis, dan Disertasi, Penerbit Alfabeta, Bandung 